\title{
AIR QUALITY AND POLLUTANTS EMISSIONS AND PROJECTIONS AT NATIONAL AND LOCAL LEVEL
}

\author{
Ph.D. Candidate Eng. Corina Oana Falup ${ }^{1,2}$, \\ 1 "Politehnica" University of Timisoara, Pta Victoriei No. 2, 300006, \\ Timisoara, Romania \\ 2 Institute for Studies and Power Engineering, Lacul Tei Blvd. No 1-3, \\ 20371, Bucharest, Romania \\ *oana.falup@ispe.ro
}

\begin{abstract}
Due to its complexity air pollution is posing multiple challenges in terms of management and mitigation of harmful pollutants. The sources of air pollutants are either natural or anthropogenic and might be emitted directly (primary pollutants) or formed in the atmosphere (as secondary pollutants). Furthermore the sources might be characterized as point, linear and surface depending on the type. As a result of air pollution policy implementation, Romania's pollutants emission have decreased over the last decades but for fulfilling a level of air quality that do not give rise to significant negative impacts on and risks to human health and the environment, action and cooperation at national and local levels as well as public engagement are needed.The paper highlights the current status of emission and the foreseen pollutant emissions evolution at national and local level. Taking into consideration the impact of air pollution on human health and environment the author analyzed the air quality of Constanta County in present and in 2020 perspective considering the local actions in air pollution domain.
\end{abstract}

Keywords: air pollution, air quality, emissions, projections, human health

\section{Introduction}

Air pollution a very important environmental and social issue is posing multiple challenges in terms of management and mitigation of harmful pollutants due to its complexity [1].

The sources of air pollutants are either natural or anthropogenic and they might be primary (direct emissions of pollutants) or secondary (pollutant emissions are formed in the atmosphere). Air pollutants may be transported or formed over long distances and they may affect large areas impacting health, ecosystems, the built environment and the climate [2]. Air pollution has caused in 2010 over 400000 premature deaths as well as substantial avoidable sickness and suffering including respiratory conditions (such as asthma) and cardiovascular problems, becoming the first environmental cause of premature death in the EU [3]. In view of 2025 and 2030 and considering the full implementation of current legislation the expected impact of air pollution on human health (premature mortality due to particulate matter and ozone) and on ecosystems will slightly improve. Thus, the impact on human health will decrease with $37 \%$ in 2025 and with $40 \%$ in 2030 relative to 2005 , whilst the impact on ecosystem area exceeding eutrophication limits will decrease with $21 \%$ in 2025 , respectively $40 \%$ in 2030 . The overall external costs associated with air pollution would remain substantial ranging between $€ 212-740$ billion [4].

\section{Legal framework}

\subsection{European policy}

The approach of European air pollution policy involves both the implementation of legal limits for ambient concentrations of air pollutants (Ambient Air Quality Directives (EU, 2004, 2008), [5], [6]) and, emission mitigation controls, to national totals as well as to specific sources or sectors (National Emission Ceilings (NEC) Directive (EU, 2001, 2016), [7,8]). 
The outcome of European air policies consisted in a decrease of pollutants emissions released into atmosphere and noticeable improvements in air quality since the late 1970s. Europe's air policy is in agreement with other conventions, such as Convention on Long-range Transboundary Air Pollution (CLRTAP) and international instruments. In order to protect human health and the environment against air pollution impacts the role of national, regional and local authorities is crucial both in implementing EU legislation and in adopting additional measures to reduce emissions and improve air quality. In late 2013 the Clean Air Policy Package for Europe has been published to ensure improvements of Europe's air quality and the decrease consequently of premature deaths by more than half of the number in 2005 relative to 2030. Clean Air Policy Package resulted in:

- Directive (EU) 2015/2193 on the limitation of emissions of certain pollutants into the air from medium combustion plants (thermal input from 1 to 50 Thermal Megawatt) entered into force in 2015 (EU, 2015), regulatingemissions of sulphur dioxide (SO2), nitrogen oxides (NOx) and fine particulate matter (PM) in order to reduce them and the human health and environment associated risks. Furthermore, rules to monitor emissions of carbon monoxide (CO) are also provided.

- A new NEC Directive (repelling2001 NEC Directive (2001/81/EC)) on the reduction of national emissions of certain atmospheric pollutants establishes new national emission reduction commitments applicable from 2020 and stricter commitments from 2030 for SO2, NOx, non-methane volatile organic compounds (NMVOCs) [1], and fine particulate matter with a diameter of $2.5 \mu \mathrm{m}$ or less (PM2.5). The new commitments are intended to reduce the health impact of air pollution by about $50 \%$ in 2030 (compared with 2005).

\subsection{National policy}

The national policy of air pollution is in line with the European one.

NEC Directive (2001/81/EC) has been transposed in national legislation through Government Decision (GD) no.1856/2005 on national emissions ceilings for certain atmospheric pollutants with subsequent modifications and additions.

Directive 2016/2284/EU on the reduction of national emissions of certain atmospheric pollutants, amending Directive 2003/35/EC and repealing Directive 2001/81/EC has not been entirely transposed yet but its provisions shall be complied.

Romania has transpose Directive 2008/50/EC on ambient air quality and cleaner air for Europe through the Law no. 104/2011 on ambient air quality.

The National Air Quality Assessment and Management System was set up to implement the provisions on ambient air quality. The system provides the organizational, institutional and legal framework for unitary cooperation for ambient air quality assessment and management and includes two systems:

- National Air Quality Monitoring System;

- National Atmospheric Pollutant Emission Inventory System.

All these legal and institutional arrangement are foreseen to assure "levels of air quality that do not give rise to significant negative impacts on and risks to human health and the environment" [8].

\section{Pollutants Emissions and Projections}

The chapter focuses on the evolution of main pollutants emissions (SO2, NOx, NMVOCs and PM) during 2005-2015 period and the foreseen emissions for the 2020-2030.

\subsection{National pollutant emissions and the commitments under European air policy}

According to the national emissions inventories reported under the CLRTAP Romania's pollutant emissions have decreased substantially over 2005-2015, the trend being in line with the European one.

The emissions decrease is due mainly to the air policy implementation.

For the year 2015 the emissions have been split on type of sources:

- Point sources;

- Linear sources: road transport, railway, domestic aviation and national navigation;

- Surface sources: urban/rural fuel consumption for residential/ commercial/ institutional heating, agriculture, waste. The share of each category in the total emissions is presented in the figure 2 . 


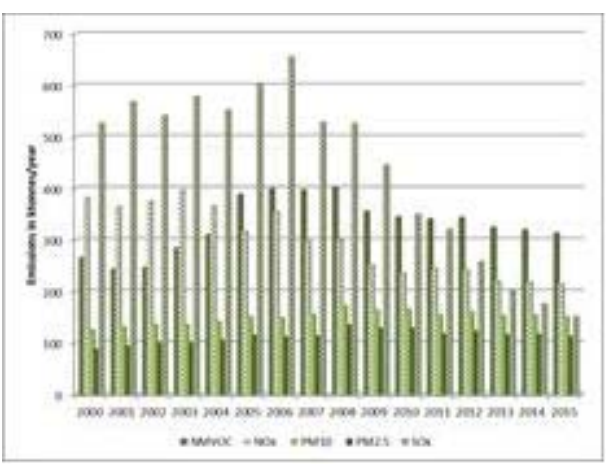

Figure 1 Evolution of national emissions during 2005-2015

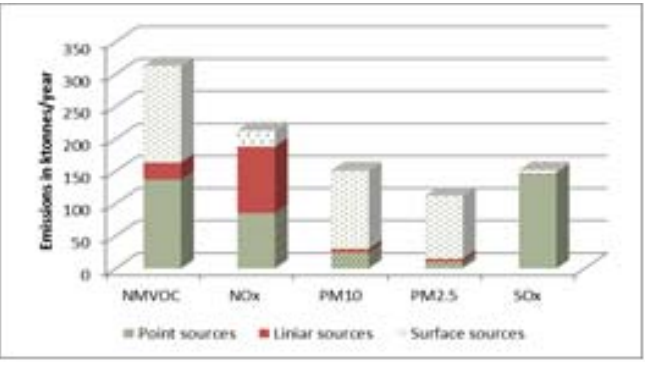

Figure 2 National emissions by sources

As for the contribution of sources to total pollutant emissions the main source of NMVOC and PM are surface sources, the main source of NOx are linear sources and those of SOx are point sources.

For the future period 2020-2030 the trend of Romania's pollutant emissions assuming that all the policies and measures regarding air pollutants emissions reductions are implemented is presented in the figure 3 .

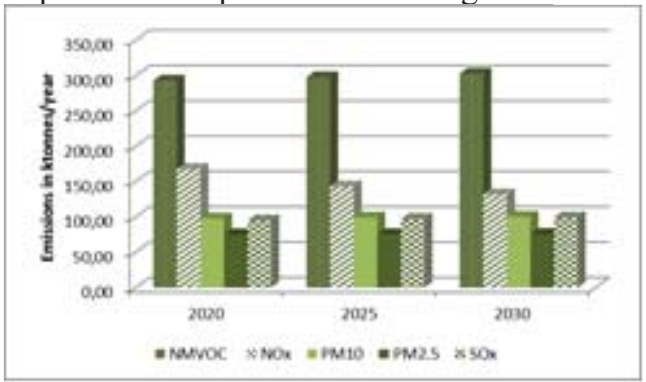

Figure 3 Forecast of national emission evolution during 2020-2030

Directive 2016/2284/EU sets national emission reduction commitments for 2020 and 2030 relative to year 2005 , as a base year. Thus national emissions ceilings for the targeted years 2020 and 2030 are presented in table 1.
Table 1 Romania emissions ceilings in 2020 , 2030

\begin{tabular}{|l|l|l|l|}
\hline 2020 \\
\hline NMVOC & NOx & PM2.5 & SOx \\
\hline 290,958 & 174,208 & 82,447 & 138,27 \\
\hline 2030 & \multicolumn{3}{|l|}{} \\
\hline NMVOC & NOx & PM2.5 & SOx \\
\hline 213,369 & 126,696 & 48,094 & 72,142 \\
\hline
\end{tabular}

Analyzing the data it seems that Romania is able to fulfill its 2020 commitments with the current legislation and measures in place but in the view of 2030 are needed additional measures to comply with the targeted ceilings.

Reducing the emissions requires effective policies, action and cooperation at national and local levels as well as public engagement.

\subsection{Air quality in Constanta County}

Contanta County is a located in southeastern part of Romania. It occupies an area of $7071 \mathrm{~km} 2$, accounting for 3 municipality, 9 cities and 247 villages. The county is limited by the Black Sea to the east, by Tulcea County to the north, by the Danube to the west and by the state border with Bulgaria in the south part.

Since 2008, Constanta County air quality surveillance has been carried out through continuous measurements by way of the automated monitoring network consisting of seven automatic stations (three industrial type stations, two traffic type stations, one station for urban background and one station for urban background).

The evolution of annual mean concentration of emissions in air during 2012-2016 is presented in the figures 5-8:

For the protection of human health and the environment as a whole the Law no. 104/2011 on air quality establishes limit values, alert threshold and critical levels for the main pollutants presented in the table no. 2:

In the analysed period the concentration of pollutant emissions in ambient air have been smaller than the legal limits values, and the trend was generally declining ( $\mathrm{NO} 2$ emissions from traffic, $\mathrm{SO} 2$ emissions from industry and traffic, PM10 emissions from industry and traffic) due to the measures took at national and local level. 


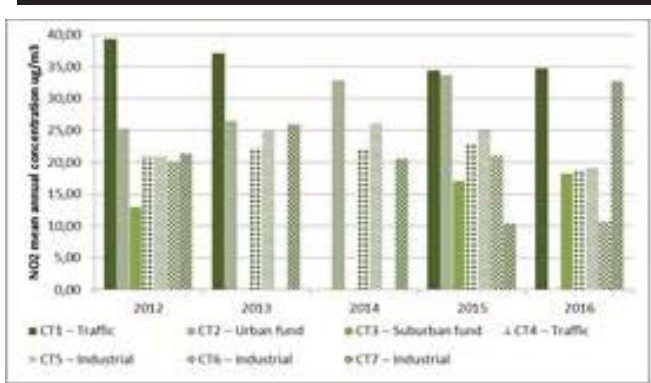

Figure 5 NO2 mean annual concentration evolution

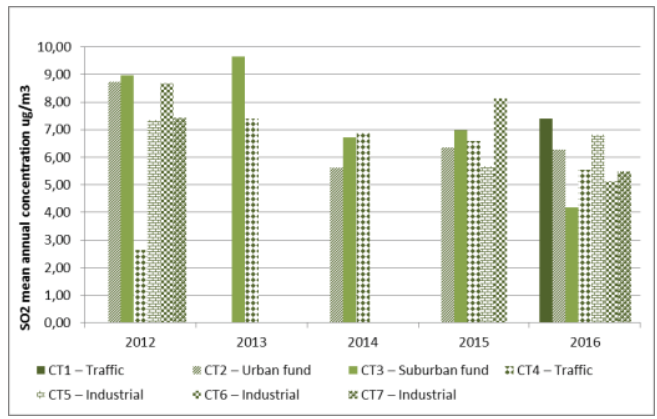

Figure $6 \mathrm{SO} 2$ mean annual concentration evolution

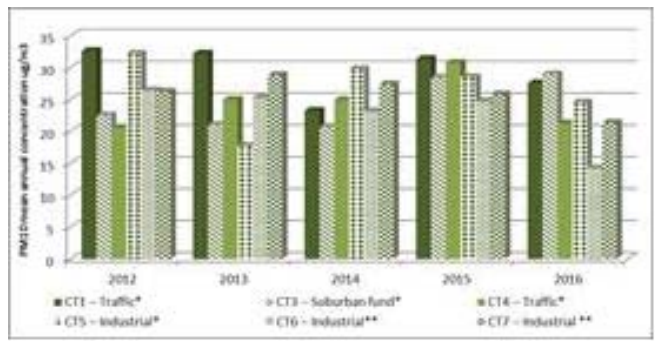

Figure 7 PM10 mean annual concentration evolution

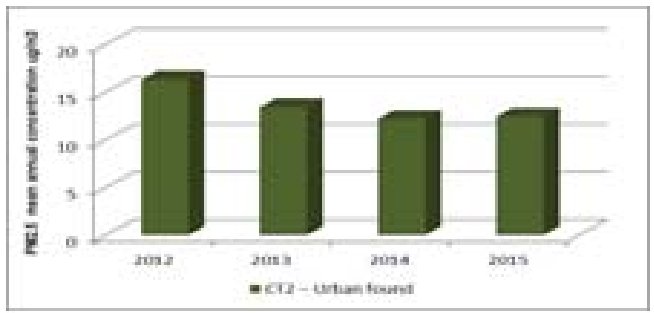

Figure 8 PM2.5 mean annual concentration evolution
Table 2 Limit values for the protection of human health and the environment

\begin{tabular}{|c|c|c|}
\hline Pollutant & Law n & $\begin{array}{l}\text { 104/2011 on air quality } \\
\text { provision }\end{array}$ \\
\hline \multirow{3}{*}{$\mathrm{NO}_{2}$} & $\begin{array}{l}\text { Limit } \\
\text { values }\end{array}$ & $\begin{array}{l}200 \mu \mathrm{g} / \mathrm{m}^{3} \mathrm{NO}_{2}-\text { one hour } \\
\text { limit value for human } \\
\text { health protection, not to be } \\
\text { exceeded more than } 18 \\
\text { times a calendar year } \\
40 \mu \mathrm{g} / \mathrm{m}^{3} \mathrm{NO}_{2}-\text { calendar } \\
\text { year limit value for human } \\
\text { health protection }\end{array}$ \\
\hline & $\begin{array}{l}\text { Alert } \\
\text { threshold }\end{array}$ & $\begin{array}{l}400 \mu \mathrm{g} / \mathrm{m}^{3} \mathrm{NO}_{2}-\text { to be } \\
\text { measured over three } \\
\text { consecutive hours at } \\
\text { locations representative of } \\
\text { air quality over at least } \\
100 \mathrm{~km}^{2} \text { or an entire } \\
\text { zone or agglomeration, } \\
\text { whichever is the smaller }\end{array}$ \\
\hline & $\begin{array}{l}\text { Critical } \\
\text { level }\end{array}$ & $\begin{array}{l}30 \mu \mathrm{g} / \mathrm{m}^{3} \mathrm{NO}_{2}-\text { calendar } \\
\text { year critical level for the } \\
\text { protection of vegetation }\end{array}$ \\
\hline \multirow{3}{*}{$\mathrm{SO}_{2}$} & $\begin{array}{l}\text { Limit } \\
\text { values }\end{array}$ & $\begin{array}{l}350 \mu \mathrm{g} / \mathrm{m}^{3}-\text { one hour limit } \\
\text { value for human health } \\
\text { protection } \\
125 \mu \mathrm{g} / \mathrm{m}^{3} \text { - one day limit } \\
\text { value for human health } \\
\text { protection }\end{array}$ \\
\hline & $\begin{array}{l}\text { Alert } \\
\text { threshold }\end{array}$ & $\begin{array}{l}500 \mu \mathrm{g} / \mathrm{m}^{3}-\text { to be } \\
\text { measured over three } \\
\text { consecutive hours at } \\
\text { locations representative of } \\
\text { air quality over at least } \\
100 \mathrm{~km}^{2} \text { or an entire } \\
\text { zone or agglomeration, } \\
\text { whichever is the smaller }\end{array}$ \\
\hline & $\begin{array}{l}\text { Critical } \\
\text { level }\end{array}$ & $\begin{array}{l}20 \mu \mathrm{g} / \mathrm{m}^{3}-\text { calendar year } \\
\text { and winter critical level for } \\
\text { the protection of } \\
\text { vegetation (1 September- } \\
31 \text { March) }\end{array}$ \\
\hline $\mathrm{PM}_{10}$ & $\begin{array}{l}\text { Limit } \\
\text { values }\end{array}$ & $\begin{array}{l}50 \mu \mathrm{g} / \mathrm{m}^{3}-\text { one day limit } \\
\text { value for human health } \\
\text { protection } \\
40 \mu \mathrm{g} / \mathrm{m}^{3}-\text { calendar year } \\
\text { limit value for human } \\
\text { health protection }\end{array}$ \\
\hline $\mathrm{PM}_{2,5}$ & $\begin{array}{l}\text { Limit } \\
\text { values }\end{array}$ & $\begin{array}{l}25 \mu \mathrm{g} / \mathrm{m}^{3}-- \text { calendar year } \\
\text { limit value for human } \\
\text { health protection, to be } \\
\text { achieved until } 1.01 .2015 \\
20 \mu \mathrm{g} / \mathrm{m}^{3}-\text { calendar year } \\
\text { limit value for human } \\
\text { health protection, to be } \\
\text { achieved until } 1.01 .2020\end{array}$ \\
\hline
\end{tabular}

\subsection{Pollutant emissions and projections in Constanta County}

According to the Inventory Emissions Report of Constanta Environmental Protection Agency the evolution of NOx, SO2 and NMVOC emissions 
during 2010-20015 is presented in the figure 9. Emissions of particulate matter are not reported.

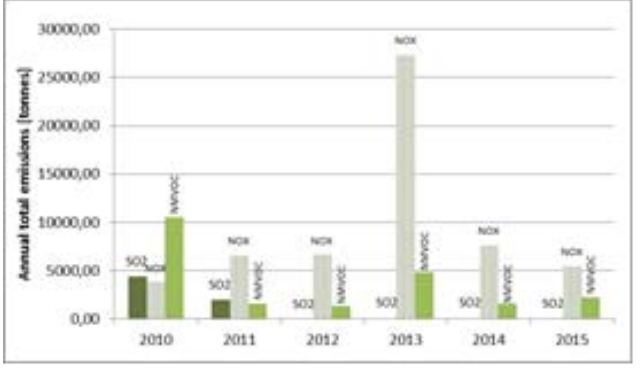

Figure 9 Pollutant emissions during 2010-2015 in Constanta County

$\mathrm{SO} 2$ emissions have decreased with $97 \%$ compared with 2010 due mainly to the implementation of NEC Directive provision (GD no.1856/2005) and Directive 1999/32/EC relating to a reduction in the sulphur content of certain liquid fuels [10] (GD no.470/2007). The emissions of PM are not reported. Using a methodology developed by author the data for 2015 have been splatted on the type of sources, furthermore PM10 and PM2.5 emissions have been estimated and projection for 2020 were performed.

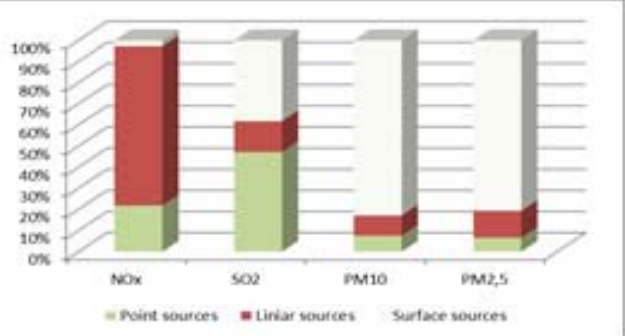

Figure 10 Constanta County emissions by sources 2015

\section{Projected emissions by sources in 2020}

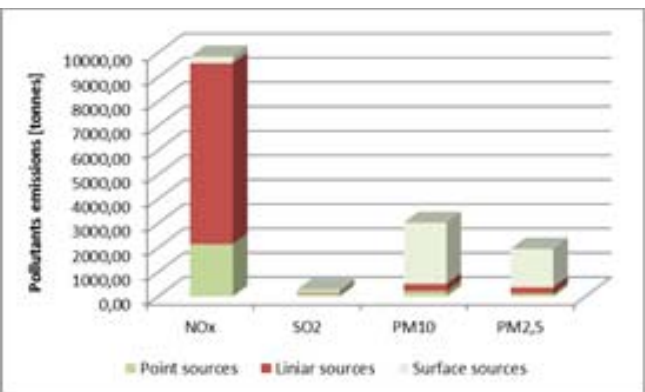

Figure 11 Constanta County emissions by sources 2020

According to figure 10 point sources are the main contributors for $\mathrm{SO} 2$ emissions, surface sources are the main contributor for PM10 and PM2.5 emissions and linear sources are the main contributor for NOx emissions.

\section{Results and discussions}

Taking into consideration the result of sources emissions estimations and modelling the data the air quality in Constanta County have resulted

\begin{tabular}{|c|c|c|c|c|}
\hline $\begin{array}{l}\text { Polluta } \\
\text { nt }\end{array}$ & $\begin{array}{l}\text { Mediati } \\
\text { on } \\
\text { period }\end{array}$ & $\begin{array}{l}\text { Type } \\
\text { of } \\
\text { source }\end{array}$ & $\begin{array}{l}\text { Estimat } \\
\text { ed value } \\
\left(\mu \mathrm{g} / \mathrm{m}^{3}\right)\end{array}$ & $\begin{array}{l}\text { Limit } \\
\text { value } \\
(\mu \mathrm{g} / \mathrm{m} \\
3)\end{array}$ \\
\hline \multirow{8}{*}{$\mathrm{NO}_{\mathrm{x}}$} & \multirow{4}{*}{$\begin{array}{l}\text { One } \\
\text { hour }\end{array}$} & Point & 96,06 & \multirow{4}{*}{200} \\
\hline & & $\begin{array}{l}\text { Surfac } \\
\mathrm{e}\end{array}$ & 14,06 & \\
\hline & & Linear & 81,21 & \\
\hline & & \begin{tabular}{|l} 
TOTA \\
L
\end{tabular} & 140,4 & \\
\hline & \multirow{4}{*}{$\begin{array}{l}\text { Calenda } \\
\text { r year }\end{array}$} & Point & 3,56 & \multirow{4}{*}{40} \\
\hline & & $\begin{array}{l}\text { Surfac } \\
\mathrm{e}\end{array}$ & 1,86 & \\
\hline & & Linear & 5,6 & \\
\hline & & $\begin{array}{l}\text { TOTA } \\
\text { L }\end{array}$ & 6,8 & \\
\hline \multirow{12}{*}{$\mathrm{SO}_{2}$} & \multirow{4}{*}{$\begin{array}{l}\text { One } \\
\text { hour }\end{array}$} & Point & 92,36 & \multirow{4}{*}{350} \\
\hline & & $\begin{array}{l}\text { Surfac } \\
\mathrm{e}\end{array}$ & 16,81 & \\
\hline & & Linear & 65 & \\
\hline & & $\begin{array}{l}\text { TOTA } \\
\text { L }\end{array}$ & 112 & \\
\hline & \multirow{4}{*}{ One day } & Point & 46,06 & \multirow{4}{*}{125} \\
\hline & & $\begin{array}{l}\text { Surfac } \\
\mathrm{e}\end{array}$ & 28,5 & \\
\hline & & Linear & 35 & \\
\hline & & $\begin{array}{l}\text { TOTA } \\
\text { L }\end{array}$ & 57 & \\
\hline & \multirow{4}{*}{$\begin{array}{l}\text { Calenda } \\
\text { r year }\end{array}$} & Point & 2,91 & \multirow{4}{*}{20} \\
\hline & & $\begin{array}{l}\text { Surfac } \\
\text { e }\end{array}$ & 0,5 & \\
\hline & & Linear & 2,3 & \\
\hline & & \begin{tabular}{|l} 
TOTA \\
$\mathrm{L}$
\end{tabular} & 7,2 & \\
\hline \multirow{6}{*}{$\mathrm{PM}_{10}$} & \multirow{4}{*}{$\begin{array}{l}\text { One } \\
\text { hour }\end{array}$} & Point & 126 & \multirow{4}{*}{50} \\
\hline & & $\begin{array}{l}\text { Surfac } \\
\text { e }\end{array}$ & 45,2 & \\
\hline & & Linear & 11,5 & \\
\hline & & \begin{tabular}{|l} 
TOTA \\
L \\
\end{tabular} & 127,5 & \\
\hline & \multirow{2}{*}{$\begin{array}{l}\text { Calenda } \\
\text { r year }\end{array}$} & Point & 9,5 & \multirow{2}{*}{40} \\
\hline & & Surfac & 8,2 & \\
\hline
\end{tabular}




\begin{tabular}{|c|c|c|c|}
\hline & & e & \\
\hline & & Linear & 0,9 \\
\hline & & $\begin{array}{l}\text { TOTA } \\
\text { L }\end{array}$ & 8,5 \\
\hline \multirow{4}{*}{$\mathrm{PM}_{2.5}$} & \multirow{4}{*}{$\begin{array}{l}\text { Calenda } \\
\text { r year }\end{array}$} & Point & 4,2 \\
\hline & & $\begin{array}{l}\text { Surfac } \\
\mathrm{e}\end{array}$ & 6,2 \\
\hline & & Linear & 0,68 \\
\hline & & \begin{tabular}{|l} 
TOTA \\
L
\end{tabular} & 6,7 \\
\hline
\end{tabular}

According to county's Statistical Yearbook 2016 the population of Constanta on 1 July 2015 was 682,375 inhabitants of which about $0.68 \%$ inhabitants in the urban area and $0.31 \%$ inhabitants in rural areas. During 2012-2015 a slight decrease in the total number of the population was registered as well as an increase of the rural population to the detriment of the urban environment.

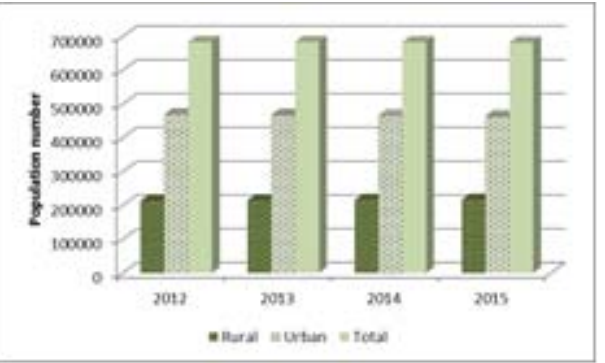

Figure 4 Constanta's population evolution

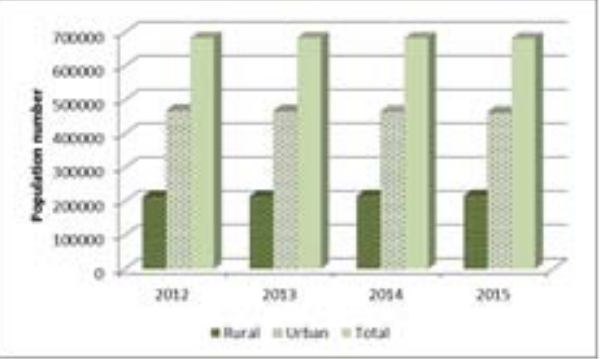

Evolution of respiratory diseases during 20082015

\section{Conclusions}

Air pollution is significantly impacting human health mainly in urban areas. Exposure to air pollution conducted in Romania to 27230 premature death (25 330 attributable to PM2.5 and 1900 attributable to NO2) and to 285600 years of life lost (265700 attributable to PM2.5 and 19900 attributable to NO2)

Considering the medical cost increase, the reduction of labour productivity, of crop yield and of life expectancy it can be stated that air pollution not only impacts humans and environment but also impacts the economy.

\section{Acknowledgment}

The paper is part of the Ph.D. program of eng. Falup Oana as Ph.D. - student at the Politechnica University Timisoara.

\section{References}

[1] European Environment Agency Air quality in Europe, Report No 28/2016, ISSN 1977 8449, page $6 . \quad$ Available: https://www.eea.europa.eu/publications/airquality-in-europe-2016 - accessed in June 2017 [2] K. Mitreski, M. Toceva, N. Koteli, L. Karajanovski: Air quality pollution from traffic and point sources in Skopje assessed with different air pollution models, Journal of Environmental Protection and Ecology 17, No 3, 840-850, (2016)

[3] European Commisson: Communication COM(2013), 918 final: A Clean Air Programme for Europe, December 2013, Available: http://eur-lex.europa.eu/legalcontent/FR/TXT/PDF/?uri=CELEX:52013DC0 918\&from $=\mathrm{EN}-$ accessed June 2017

[4] International Institute for Applied Systems Analysis IIASA: TSAP-2012 Baseline: Health and Environmental Impacts, Report \#6, November $2012 \quad$ Available: http://ec.europa.eu/environment/air/pdf/tsap_im pacts.pdf - accessed 12 June 2017

[5] Directive 2004/107/EC relating to arsenic, cadmium, mercury, nickel and polycyclic aromatic hydrocarbons in ambient air, Available: $\quad$ http://eur-lex.europa.eu/legalcontent/EN/TXT/?uri=CELEX\%3A32004L010 7 - accessed June 2017

[6] Directive 2008/50/EC on ambient air quality and cleaner air for Europe, Available: http://eurlex.europa.eu/legal-content/EN/ TXT/? uri= CELEX:32008L0050 - accessed June 2017

[7] Directive 2001/81/EC on the reduction of national emissions of certain atmospheric pollutants, Available: http://eur-lex.europa. eu/legal-content/EN/TXT/?uri=CELEX\%3

A32001L0081 - accessed June 2017

[8] Directive 2016/2284/EU on the reduction of national emissions of certain atmospheric pollutants, amending Directive 2003/35/EC and repealing Directive 2001/81/EC Available: 
http://eur-lex.europa.eu/legal-

content/EN/TXT/?uri=uriserv:OJ.L .2016.344.

01.0001.01.ENG\&toc=OJ:L:2016:344:TOC accessed June 2017

[9] H. Stevanovic-Carapina, N. Zugic-Drakulic, M. Kasanin-Grubin, A. Mihajlov: Assessment of Air Pollution Impact on Human Health in Pancevo, Serbia, Journal of Environmental Protection and Ecology 12, No 4A, 2360-2366 (2011)〉

[10] Directive 1999/32/EC relating to a reduction in the sulphur content of certain liquid fuels, Available: http://eur-lex.europa.eu/legalcontent/EN/TXT/?uri =celex: 31999L0032 accessed June 2017 